\section{EMBRYRIDDLE}

Aeronautical University

SCHOLARLY COMMONS
Journal of Aviation/Aerospace

Education \& Research

Volume 3

Number 4 JAAER Summer 1993

Article 2

Summer 1993

\title{
Aviation \& Aerospace Education: A Positive Impact on the 21st Century
}

Patricia Fleener-Ryan

Follow this and additional works at: https://commons.erau.edu/jaaer

\section{Scholarly Commons Citation}

Fleener-Ryan, P. (1993). Aviation \& Aerospace Education: A Positive Impact on the 21st Century. Journal of Aviation/Aerospace Education \& Research, 3(4). https://doi.org/10.15394/jaaer.1993.1099

This Article is brought to you for free and open access by the Journals at Scholarly Commons. It has been accepted for inclusion in Journal of Aviation/Aerospace Education \& Research by an authorized administrator of Scholarly Commons. For more information, please contact commons@erau.edu. 


\title{
AVATION \& AEROSPACE EDUCATION: A POSITIVE IMPACT ON THE 21ST CENTURY
}

\author{
Patricia Fleener-Ryan
}

Are we "A nation still at risk"? (Newsweek, 1993) Ten years ago the National Commission on Excellence in Education published a gloomy picture of the state of the American educational school system. The commission predicted that the country would be consumed by a "rising tide of mediocrity" in elementary and secondary schools unless major changes occur within the system. According to the latest news reports from Associated Press and Newsweek magazine, yes, this Nation is still at risk--"real change has been remarkably slow" (p. 46).

Issues cited in these 1993 news reports, for example, are:

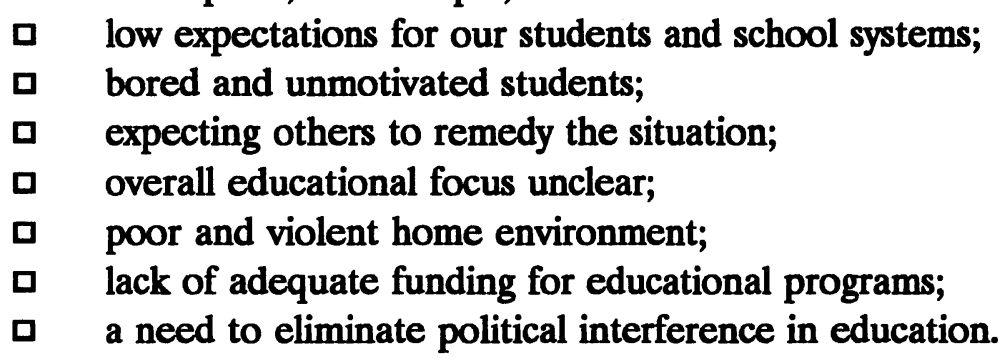

As reported in the Daytona Beach Sunday News-Journal (Educators Remain Critical, 1993) a very bleak view was written in the April 1993 issue of Phi Delta Kappan by Emeral A. Crosby, principal of Detroit's Pershing High School. Crosby wrote, "Our children might be better off if they declared sovereignty and then asked for foreign aid" (p. 6A). The point here is that our American educational school systems need to be given higher priority at all levels in our government and society.

\section{INTRODUCTION}

The time is ripe for new and innovative ideas to emerge to offset the downward spiral in student motivation and performance. Aviation/aerospace educators need to become more actively involved in the American educational system and enrichment programs.

First, however, we need to examine the issues and determine the future of aviation and space education in relation to these "bleak" times in the history of America's educational programs. Also we need to be aware of emerging technologies and how these technologies can enhance and/or implement education reforms using an aviation and space education approach. Issues concerning the role of the federal and state government, industry, and academia in aviation and space education need to be addressed as well as the cultural diversity in aviation and space education.

Dr. C. Elaine McCoy wrote in the 1990 University Aviation Association Fall Education Conference Proceedings that "Aviation programs encompass the development of skills ranging from the technical to those of human interaction and decision-making. Such diversity strengthens the discipline and reflects the various demands of the industry" (p. i). Aviation and aerospace educational programs have been used beneficially as a teaching/ learning tool in education for several decades with documented success.

\section{TASK FORCE APPOINTED}

Looking back in the history of aviation and aerospace education, California is noted as being heavily involved in the application of the aviation/aerospace sciences in education early in the 1970s. In 1971, then California 
governor Ronald Reagan created an Office of General Aviation. He further appointed a task force to specifically investigate the uses and benefits of various aviation/ aerospace applications, as teaching/learning tools in the elementary and secondary schools of California. This task force concluded that the State of California should assume a positive role in sponsoring and supporting greater development in aviation and aerospace education offerings, and that the benefits would far outweigh the costs of implementing these programs (Report of the Governors Task Force..., 1971).

The following statement made by Governor Reagan to the Aerospace/aviation Education Task Force in June 1969 provides a reason for incorporating aviation and space education in our classroom activities: "The complexities of this air age demand that our educators bend their efforts toward adapting space and aviation concepts to the task of furnishing our young people a sound basis of understanding of the world around them" (p. Preface).

A Teacher's Guide to Aerospace Sciences, published by the Lincoln, Nebraska Public Schools, summer of 1966, states: "The aviation and aerospace society in which we now live is yesterday's dream, today's frontier, and tomorrow's life" (Office of General Aviation, 1971, p. 4).

\section{MULTI-LEVEL CURRICULA DEVELOPED}

We are in that "tomorrow's life" now. Multi-level aviation and aerospace curricula have been developed and these multi-level curricula are offered free to all interested individuals through the Federal Aviation Administration (FAA), the U. S. Department of Transportation (DOT), the Civil Air Patrol (CAP), the General Aviation Manufacturers Association (GAMA), the Beech Aircraft Corporation, the Cessna Aircraft Company, and the Airline Owners and Pilots Association (AOPA), to mention just a few.

\section{Magnet and Saturn Schools Initiated}

Moreover, successful programs using aviation and aerospace in the classroom have occurred throughout the United States and the world. Teacher workshops are offered to encourage and assist educators in incorporating the various aviation/aerospace concepts and materials into the classroom. "Magnet" and "saturn" schools have been initiated and are utilizing aviation and aerospace across the curriculum to teach the concepts and skills designated by the educational systems. Summer youth programs across the nation are promoting aviation awareness and potential career choices. Recognition and awards are given to educators by national aviation and aerospace organizations and individuals to encourage participation and high standards of excellence in teaching. However, the impact of these programs remains localized, and the success is measured accordingly.

\section{DEVELOPING AN EDUCATIONAL FOCUS}

The future of aviation and aerospace education lies in addressing the national, state, and local educational needs with a program proven to be highly motivating--a program that offers the opportunity to teach, practice, and apply relevant concepts and skills to students wanting to succeed in the modern world.

However, effort must be made to reach beyond the immediate area. Cooperation and support of major state and national leaders in education must be gained. For example, the Florida Aerospace Education Association was formed a few years ago to organize individuals interested in developing and promoting aviation and aerospace education. A quarterly newsletter is published which offers a vehicle for sharing of ideas and keeping current with upcoming aviation and aerospace events. The success of this effort depends on the interest and participation of the members and the growth of the organization. Membership includes individuals from the Air Force Association (AFA), the Florida Department of Transportation, the educational institutions, and from business and industry.

\section{SERVE}

Educators who have created and implemented successful aviation/aerospace classroom activities should share their programs with SouthEastern Regional Vision for Education (SERVE). SERVE's mission is to operate as an education laboratory providing leadership, support, and research to assist state and local efforts in improving educational outcomes. SERVE also offers a series of publications addressing issues of present relevance and importance in education, which are practical guidebooks for educators (Jordan, 1993).

In the January 1993 publication, Using Technology to Improve Teaching and Learning, the editors explained: 
Technology can fill the gap between the promise and the reality of educational computing, but it will take motivated, innovative, and informed teachers to bridge it. . . . To meet educational challenges of the 21st century, we must "think in the future and act in the present." (Thornburg, 1991, p. 111)

\section{CACEL}

Aviation and space education uses technologies to illustrate and apply aviation and aerospace concepts. For example, I developed the Computer-assisted Aviation Career Exploration Lab (CACEL) to provide more experiential learning opportunities for $\mathrm{K}-12$ students. The CACEL program utilizes computer technology to simulate and incorporate flight and air traffic control skills. An intercom/radio communication system with headsets adds to this realistic but simulated scenario. Meteorology/flight service and flight ground school stations are part of this aviation simulated educational adventure. The interest from public and private school systems has been overwhelming. Since the opening of this lab in mid December 1992, more than 1,010 K-12 students, teachers, and parents have successfully participated in the CACEL multi-career experience, and 17 additional tours (approximately $760 \mathrm{~K}-12$ students and adults) are scheduled for the CACEL program before the first of June 1993.

Computer-based curriculum materials and simulation using aviation/aerospace concepts capture the interest and attention of students and have relevance for future application. "Technology-based activities offer many opportunities for students to reconstruct and produce knowledge in ways that have intrinsic value and will benefit them in their personal and professional lives" (Jordan, 1993, p. 46).

\section{THE CHALLENGE OF NEW FRONTIERS}

Aviation and aerospace involves past, present, and future application incorporating the newest and latest educational technologies. It is the challenge of the schools, however, to foster an atmosphere in which students can be creative, unbridled, and innovative thinkers who will conquer the new frontiers the space program creates.

\section{Model School Act}

In 1985, the Florida Legislature passed the Florida
Model School Consortia Act to:

Strengthen the public school system by establishing prototype technology schools throughout the state. These schools experiment and conduct research on how educational technology can be most efficiently and effectively incorporated into schools. Goals of the program are to prepare students for the "rapid changes in society brought about by the infusion of technology in all aspects of lifen and to encourage teachers to incorporate technology into their teaching, learning, and management functions. (Jordan, 1993, p. 15)

Embry Riddle Aeronautical University serves as a partner to Mainland High School, Daytona Beach, which was chosen as one of the two designated high schools in the State of Florida.

\section{A Changing Role}

Certainly, the role of schools in this new age of space and high technology is drastically changing, putting much greater emphasis on content and job relevancy. Aviation and space education is ideally suited to meet these challenges.

The role of the federal and state governments, industry, and academe in aviation and space education must be one of cooperation and team effort. "Rapid changes in world economic conditions are creating enormous pressures on business and industry to become more competitive and help their employees become more productive" (Gustafson, Feb. 1993, pp. 28-29). Business and industry have a vested interest in the educational systems for future human resources with skills and abilities that will fulfill their needs. Federal agencies such as the FAA are committed to helping meet rapidly changing technology by supporting sound education for all students.

\section{Cultural Diversity}

Cultural diversity in aviation and space education is achieved by placing emphasis on the person as a unique individual. Aviation and space education and activities attract all types of people from all walks of life and cultures. The examples of individuals from all cultures serve as role models to encourage the youth of today to 
plan and set goals for tomorrow. All students, no matter what their cultural background, need to be aware of the benefits and opportunities that aviation and space education has to offer.

\section{SUMMARY}

How much impact aviation and aerospace education has on the 21st century depends on each of us. Our nation needs our commitment and dedication to help educate the youth of today to be more knowledgeable and resourceful contributors in tomorrow's society. It is time to focus on higher standards and expectations in our education systems.

We need to take control and take charge to remedy this "mediocrity." Using aviation and space education to set high standards for achievement and to motivate and encourage bored and uninterested youth has proven to be cost effective and educationally beneficial.

Educators and politicians alike call for education that is responsive to the future needs of the student and to the changing goals of a technologically advanced country. Aviation and space can be the driving force that causes students of all cultural background to excel. It is the duty of schools, governments and industry to reach students to help develop their self-confidence and assist them to visualize a valuable future.

The Teacher Resource Center at Embry Riddle Aeronautical University has a visual proclaiming our theme of AIM HIGH! The acronym "AIM" is derived from:

Aviation and space education

Imagination

Motivation

We need to employ the embodiment of AIM in what we are teaching today so that our youth can AIM HIGH in their goals and expectations--which will make a positive impact on the 21st century!

Patricia Fleener-Ryan, Director and Coordinator of the Federal Aviation Administration Aviation Education Teacher Resource Center at Embry Riddle Aeronautical University, earned a Masters of Arts degree in Instructional Technology and a Bachelors of Science in Elementary Education. Ryan is the 1993 winner of the A. Scott Crossfield Aerospace Education Teacher of the Year award. In 1990 she won the FAA Southern Region Award and the National Aviation Education Individual Champion Award. In addition to serving as an Educational Specialist for the Civil Air Patrol, Ryan also conducts workshops, institutes, and youth programs.

\section{REFERENCES}

A nation still at risk. (1993, April 19). Newsweek. p. 46.

Educators remain critical of schools 10 years after report. (1993, April 25) Daytona Beach Sunday News-Journal. p. 6A.

Gustafson, K. L. (1993, February). Instructional design fundamentals: Clouds on the horizon. Educational Technology. Englewood Cliffs, NJ.

Jordan, W. R. (1993, January). Using technology to improve teaching and learning. SouthEastern Regional Vision for Education. Tallahassee, FL.

McCoy, C. E. (1990) 1990 University Aviation Association: Fall Education Conference Proceedings. University Aviation Association.

Office of General Aviation. (1971.) Report of the governors task force on aerospace/aviation education. Washington, D.C.: Government Printing Office.

Thornburg, D. D. (1991). Education, technology, and paradigms of change for the 21st century. San Carlos, CA: Starsong. $\square$ 